\title{
The various modes of existence of space and the idea of "nation" in the making of European geographies: the case of 20th century French geography
}

\author{
B. Debarbieux \\ University of Geneva, Geneva, Switzerland
}

Correspondence to: B. Debarbieux (bernard.debarbieux@unige.ch)

Received: 5 February 2013 - Accepted: 13 February 2013 - Published: 30 May 2013

\begin{abstract}
Drawing upon the example of 20th century French geography, the paper argues that the production of knowledge on nations and national territories by geographers is significantly influenced by how geographers are embedded within national institutions when producing this knowledge. More specifically, the paper shows how the conflation of the nation state as a category of knowledge and as a category of action and the interaction of the various "modes of existence of space" according to which the idea of nation has been seized have indeed deeply shaped French geography both at the beginning and at the end of the 20th century.
\end{abstract}

\section{Introduction}

In 2002, the journal Geopolitics produced an issue devoted to the concept of "nation" in an unusual way (Geopolitics, 2002). For this themed issue devoted to the nation-building process, the journal editor, Anthony D. Smith, following a proposal made by Walker Connor (1990), put aside the now common question "What is a nation?", asked countless times since the American and French revolutions, for another one, "When is a nation?", on which he solicited contributions from several authors. This change of perspective led to an interesting debate on the conditions required for the building of a nation and on the processes leading up to this.

For the present theme issue, devoted to linguistic and national traditions in geography, I would like to introduce my own contribution to the debate with a third question, "How is a nation?" This unusual, somewhat awkward way of questioning the concept of "nation" will allow me to shed light on both the ontological and epistemological nature of this notion. More precisely, it will allow me to argue that the production of knowledge on nations and national territories by geographers is significantly influenced by the way geographers shape national institutions when producing this knowledge.

In what follows, I will first explain in more detail the key problematic of this contribution, drawing on examples taken from various fields of scientific knowledge production. Second, I will then explore the ways in which French geographers, at the beginning and at the end of the 20th century, have dealt with the concept of the "nation".

\section{Narratives and modes of existence of space in the production of scientific knowledge}

In dealing with the question "How is a nation?", it is possible to examine the various modes of existence of nations. The notion of "mode of existence" is borrowed from Gilbert Simondon (1989), more than from Etienne Souriau (1943) or Bruno Latour (2009) who recently reframed it in his analysis of modernity. In Simondon's work, questioning the mode of existence of biological or social individuals is a way to examine how the process of individuation takes place.

Why do I need to shape my reflection in such an unusual way? Why is there an advantage in analysing the modes of production of geographical knowledge from such a standpoint? An answer can be given with a detour in the various narratives resulting from academic studies that set out to examine the spatial dimensions of the production of scientific knowledge.

Alexandre Koyré's history of the revolution in astronomical knowledge in the 16th and 17th centuries (1957) is 
probably one of the most impressive examples of the classical way of looking at the history of science. Koyré strove to explain how cosmic space, seen as an empirical space, had been understood according to different kinds of abstract spaces invoked by leading authors of the time: Copernicus, Galileo, Descartes, Tycho Brahe and Kepler. He never felt the need to explain anything in his history of astronomical ideas on the basis that Copernicus was Polish, that Galileo was born and trained in Tuscany, that Descartes was French but living in the Netherlands, that Tycho Brahe was Danish or that Kepler was from Württemberg. His analysis owed nothing to the contextual conditions in which their ideas had been shaped. But some more recent historians of science have been interested in explaining the revolution of modern astronomy in relation to places of encounters, circulation of ideas at the European scale, local disputes and, for some, trials. In doing so, they have complemented the two kinds of space specified by Koyré - empirical space and abstract space - with two complementary spaces in their own analysis: the space where these astronomers were living such as Galileo's, with the strong influence of the Roman church on all kinds of social knowledge - which we can call socio-cultural space - and the space shaped by the circulating books, images and people of the time - which can be named space of action or praxeological space. One can say that referring to these four spaces - empirical, abstract, sociocultural and praxeological - is useful for understanding why, how, and when this astronomical revolution took place. But these spaces are of very different kinds and so not liable to influence each other. Indeed, the spatial character of the respective contexts and modes of work of these astronomers has nothing in common with the kind of space they include in their theoretical discussions. Abstract space deserves to be seen as a category of knowledge, socio-cultural space as a frame of practices and praxeological space as a category of action.

What about geography then? It is not surprising that the birth of modern geography has often been associated with Alexander von Humboldt, whose main contribution to scientific knowledge was to relate every empirical observation in botany or geology to macro-systems of terrestrial and cosmic localisations and explanations, based, again, on a geometric conception of space. However, Humboldt's quest for science can also be described in cultural terms. We need to bear in mind that he was Prussian and a close friend of Goethe and other German Romanticists, that he lived a long time in Paris, was very Francophile and willing to take the best from the rationalism of the French Enlightenment. We should also bear in mind the fact that instruments, maps, drawings and flows of immutable mobiles played a decisive role in the building of his own understanding of the terrestrial surface. But again, the corresponding spaces are of very different kinds. His geography of plants and his geognosy, both for its empirical dimension and the abstract models he used for its understanding, had nothing in common with the socio-cultural space he experienced in Europe and Latin America, or with the praxeological space drawn by his instruments, drawings or the meetings he took part in.

\section{The interaction of the various modes of existence of space when geographers deal with "nations"}

So far, I have only recalled the ways academic studies have analysed the production of scientific knowledge according to various narratives and various spatial dimensions. Now I would like to question the various modes of existence of space of the production of scientific knowledge for human geographers of the 20th century, especially when they focus on nations and national territories. In attempting to understand the production of knowledge in human geography as well as the production of astronomical or biological knowledge, it is helpful to refer to different kinds of spaces - empirical space, abstract space, socio-cultural space and space of action. However, the interaction between these kinds of spaces is potentially much higher in geography compared to astronomy and biology. And this interaction is more prone to lead to a conflation of these different kinds of spaces. What do I mean by this?

Geographers of the 20th century have been very interested in understanding how humanity has been more or less shaped into nations and national territories. But this work has been undertaken at a time when geography became institutionalized according to national frameworks. Early decades of the 20th century witnessed the foundation of national associations, national journals, public universities with professorships in geography, national congresses, and in some cases national procedures of academic recognition, etc. These institutions and practices strongly shaped what Pierre Bourdieu called homo academicus and the "spaces of academic positions" (1984), and determined the building of agreement or disagreement within the discipline. Therefore, spaces of action for geographers became strongly shaped according to a spatial matrix, which was very close to the one they adopted as an object of knowledge. This led to a huge potential for conflation between empirical space as an object of knowledge, abstract space as a category of knowledge, sociocultural space as a frame of action, and praxeological space as category of action within the daily work of geographers.

I would like to illustrate this by comparing two periods of French geography: the famous French School of Geography of the early 20th century and the not so well known academic landscape of the 1980s and 1990s. I would also like to explain how geographers have dealt with this plurality of spaces. 


\section{The category of "nation" in the French School of Geography in the early 20th century}

In my view, the two most salient characteristics of the French School of Geography at this time were the following:

- Its exponents' main model of abstract space was both "atomistic" and "partitional". Atomistic meant that, for them, empirical space was first of all a collection of places - each of which was a tiny piece which could not be divided into smaller units without losing its very nature. Partitional meant that this empirical space was ontologically divided into coherent units - let us say "regions", "natural regions" or "territories", which may include "national territories". This abstract space is borrowed from modern physics, which, as shown by philosophers such as Michel Serres, is mainly interested in what he calls "hard objects" and sets of hard objects with what he calls "sharp edges" (Serres, 1980).

- This two-fold paradigmatic model of knowledge described above was complemented by a third one, borrowed from ecology: the concept of the "milieu" postulates that things and beings located at the same place or in the same region interact to such a point that they mutually influence each other. This means that collective bodies - such as nations - and specific spatial entities territories - are co-determined.

Thanks to this three-fold abstract spatiality, terrestrial space was seen as a set of supra-national entities made of contiguous national territories, whereas national territories were seen as sets of contiguous sub-national, regional entities and humanity as a set of collective bodies, nations and communities, etc.

Indeed, this feature was not specific to French geography. A similar paradigm was at work in German and American geography too. However, it was particularly strong in French geography. We should bear in mind how illustrative of this way of thinking the so-called Géographie Universelle, published between 1927 and 1948 (Vidal de la Blache and Gallois), was a living proof of the belief in the universality of this spatial model of thought ${ }^{1}$.

But this production of knowledge on nations, regions, regional and national territories - as categories of knowledge - cannot be understood without bearing in mind that nations and national territories became at the same time institutional frames of action for the same geographers, as shown by Berdoulay (1981), among others. Consider the following:

\footnotetext{
${ }^{1}$ Similar statements have been uttered by anthropologists when writing about the so-called traditional communities: as shown by Hobsbawm and Ranger (1983) in the Anglosphere, or Amselle (1990) in the Francosphere and many other recent analysts, non-European societies have been framed according to similar conceptions of space and milieu for fixing the so-called tribes or ethnicities in bounded territories.
}

- The French School of Geography was shaped as a national institution, which meant it had strong internal rules, networks of cooperation and solidarity, as well as a strategy of occupying academic positions.

- The academic output of the time - the set of regional studies and the Géographie Universelle itself for example - displays how far this school shared among its members the view that French territory and colonies as well as the whole world were academic territories.

- The French School of Geography defined its own criteria of academic orthodoxy. A first generation of geographers trained by Paul Vidal de la Blache selected from Vidal's works some publications (such as Tableau géographique de la France, 1903, see also Robic, 2000) and concepts (such as genre de vie) which could fit the doxa, and put aside some other texts (such as La France de l'Est, 1917), topics and concepts (on political geography, borders, circulation and flows) which were seen as peripheral to this doxa.

- Those who were not exponents of the same kind of orthodox geography have been marginalized (such as Marcel Dubois, Camille Vallaux) or academically exiled (such as Jean Gottmann).

This selection of Vidal's heritage and the internal structure of the school can be seen as a purification of its academic discourse and organization.

Altogether, these institutional practices were adopted within the framework of the nation state, which allowed us to talk about a French (and not a French speaking) School of Geography. Therefore, for these geographers, the nation state was both a category of knowledge and a category of action, but nothing in the research programme of this orthodox geography explicitly linked the two. This school had emptied its research programme of any social and political content, deliberately forbidding itself to conceptualize the nation state as a social, political and ideological construct, contrary to some marginalized proposals such as Gottmann's in his $L a$ Politique des États et leur géographie (1952).

The only conceptual connection, a very implicit one indeed, which can be made between the nation state as a category of knowledge and the nation state as a category of action as conceived by the French School of Geography, can be found in the way these geographers related their objects and their actions to the idea of identity and, going back to Simondon, to individuation. Regarding the spatial objects they put under academic scrutiny, they focused their attention on defining the so-called geographic specificity of each of them, what Vidal called its "personnalite" (1903). Meanwhile, these geographers were very eager to cultivate their own personnalité in the field of academic geography, deliberately distancing themselves from German geographers and promoting a French way of doing geography. In so doing they 
cultivated a national identity among geographers and other scientists. Thanks to internal rules of academic recognition, they drew spaces of identity and lines of difference within the academic field, which were to be very similar to the ones they drew on maps for delineating their objects of knowledge.

\section{Continuities and new trends in French geography of the last decades}

What are the similarities and differences between French geography in the early twentieth century and French geography in the most recent decades, particularly since the 1980s? Curiously, some of the earlier features have been kept alive despite the fact that a profound renewal of the scientific content of the discipline has taken place. The following items strive to establish where the national issue now lies:

- The academic regulation of the discipline has remained very strong, possibly the strongest among European countries. Public universities' practices in terms of teaching and research have remained very much coordinated or regulated by national institutions and practices: administrative regulation of academic programmes and curricula, disciplinary committees for preselecting candidates for academic positions, evaluation of researchers, national funding programmes for research, official ranking of journals, etc. Moreover, these national institutions and practices have made little use of international expertise.

- If strategies for building academic orthodoxy have been weakening, the definition and control of intellectual norms remains significant. A strong theoretical and thematic renewal actually took place from the 1970s to the 1990s. Most of it was influenced by Anglo-American geography (such as quantitative geography, behavioural geography, etc.), some of it by continental existentialism. But the second wave of innovations in the Anglophone world was blocked out by French geographers, so post-modernism, post-colonialism, post-nationalism and post-structuralism - in a word, all post-movements - have been regarded with deep suspicion (see as an example the interesting debate on postmodernism in geography in L'Espace Géographique, 2004). This uncompromising attitude towards the various sources of renewal can be strongly related to the question of identity. Quantitative and behavioural geographies were often said to be very close to French rationalism, which severely despised all "post-something" geographies as being non-scientific or unable to meet the expectations of French rationalism.

- The will to cultivate a combination of some kind of academic identity and scientific universalism was especially strong in the making of the fourth Géographie Universelle issued between 1990 and 1996 (Brunet et al., 1990-1996). This impressive work, undertaken by many of the most prominent French geographers of the time, following different kinds of scientific paths, served as a common, uniting, project.

- This led to a somehow paradoxical situation; French geography kept a strong ideal of universalism, but it was at the same time very concerned with its own identity and specificity. This led French geography to lose ground in international debates, despite a set of important proposals which would have deserved more attention of the global, mostly Anglophone, academic world.

- What took place in the specific domain located somewhere between geography and politics is especially illustrative of the national issue in the making of contemporary geography in France. During the 1980s and 1990s, we witnessed the re-emergence of French geographers who had been deliberately forgotten (such as Elisée Reclus), left aside (such as Jacques Ancel) or somehow expelled (such as Jean Gottman) during the former period. All of them had been very active in analysing the process of nation- and state-making, sometimes focusing on the French case. Therefore, the revival of political and critical geography and epistemology among French geographers during the later decades of the 20th century led to the recognition of alternative geographers, who were once absent from national orthodoxy; they were used as new figures for a new orthodoxy, somehow national, thanks to their French nationality.

- Indeed, political geography experienced an interesting comeback in the French academy. However, this revival mainly followed Lacoste's proposals, built on neoMarxist theories of nation and state geopolitics (as displayed in the very popular journal he founded in the mid-1970s, Herodote), rather than Raffestin's (1980, see also Klauser, 2012), which were much more open to a relational, Foucaldian, conception of power, where the state is one type of actor amongst others and where decisive factors are the circulation of information, images and goods.

Together, the features mentioned so far prove that, despite a deep renewal of academic paradigms and methodologies in French geography, the nation state remained a relevant category of academic practices both as a category of knowledge, and as a category of action. But compared to the French School of Geography in the first half of the century, late 20th century geographers were conscious about the connection between the two categories and somehow eager to play with it: they utilised reflexivity extensively and they strongly engaged either in some kind of critical geopolitics or in applied geography with national administrations, especially in the field of regional planning. 
In my view, this strong and dual attention to the category of nation is one reason for the very late incorporation by French scholars of major topics of today's geography such as globalization, transnationalism, and multiculturalism. French society and politicians may not have been open to these debates. But geographers more specifically had kept a somehow national way of thinking and doing, which made the relativisation of the concepts of nation, state and territory more difficult or even dangerous in their own vocabulary.

\section{Final remarks}

Having posed the question "How is a nation?", I would now like to reflect on my contribution to the debate opened by this special issue and by the related conference held in Fribourg. My key argument here has been the following: the various modes of existence of space in the production of knowledge are potentially conflated when geographers deal with states, nations and national territories. Contrary to the "cosmos" of modern astronomy, these entities can be simultaneously seen as social and spatial categories of knowledge, frames of practices and categories of action. Furthermore, I have argued, as an illustration, that the conflation of these modes of existence has influenced French geography all throughout the 20th century. Therefore, the analysis of empirical space, which is the very starting point of any geographical project, was instead influenced by the national framing of scientific and academic questions. In a word, with 20th century French geography and probably some others, we may have witnessed a revealing illustration of what Ulrich Beck has called "methodological nationalism" (2006).

Acknowledgements. I warmly thank Francisco Klauser, Benedikt Korf, and Ola Söderström for providing me the opportunity to develop the idea of this paper in the frame of a seminar organized in Fribourg in October 2012, and for discussing fruitfully its content. I am also grateful to several academic groups of French geographers for having involved me in many editorial projects within which I have been trained to scientific thinking, including critical thinking.

Edited by: B. Korf

Reviewed by: one anonymous referee

\section{References}

Amselle, J. L.: Logiques métisses: anthropologie de l'identité en Afrique et ailleurs, Payot, Paris, 1990.

Beck, U.: Cosmopolitan Vision, Polity Press, Cambridge, 2006.

Berdoulay, V.: La formation de l'école française de géographie (1870-1914), CTHS, Paris, 1981.

Bourdieu, P.: Homo Academicus, Les Éditions de Minuit, Paris, 1984.

Brunet, R. (Ed.): Géographie universelle, Paris, Hachette; Montpellier, Reclus then Paris, Belin; Montpellier, Reclus, 1990-1996.

Connor, W.: "When is a Nation?", Ethnic Racial Studies, 13/1, 92103, 1990.

Espace Géographique: Theme issue on "La Géographie postmoderne", 33/1, 2004.

Geopolitics: Theme issue on "When is a nation", 7/2, 2002.

Gottmann, J.: La Politique des États et leur géographie, Armand Colin, Paris, 1952.

Hobsbawm, E. and Ranger, T. (Eds.): The Invention of Tradition, Cambridge University Press, Cambridge, 1983.

Klauser, F. R.: Thinking through territoriality: introducing Claude Raffestin to Anglophone sociospatial theory, Environ. Plann. D, 30, 106-120, 2012.

Koyré, A.: From the Closed World to the Infinite Universe, John Hopkins Press, Baltimore, 1957.

Latour, B.: Sur un livre d'Etienne Souriau: Les Différents modes d'existence, http://www.bruno-latour.fr/fr/node/207 (last access: 31 January 2013), 2009.

Raffestin, C.: Pour une Géographie du Pouvoir, Litec, Paris, 1980.

Robic, M.-C. (Ed.): Le Tableau de la Géographie de la France de Paul Vidal de la Blache, CTHS, Paris, 2000.

Serres, M.: Hermès V, le passage du nord-ouest, Les Éditions de Minuit, Paris, 1980.

Simondon, G.: Du mode d'existence des objets techniques, Aubier, Paris, 1989.

Souriau, E.: Les différents modes d'existence, PUF, Paris, 1943.

Vidal de la Blache, P.: Tableau géographique de la France, Hachette, Paris, 1903.

Vidal de la Blache, P.: La France de l'Est, Armand Colin, Paris, 1917.

Vidal de la Blache, P. and Gallois, L. (Eds.): Géographie Universelle, Armand Colin, Paris, 1927-1948. 